\section{Increasing the microbial carbon sink in the sea by reducing chemical fertilization on the land}

\author{
Nianzhi Jiao, Kai Tang, Haiyuan Cai and Yujiao Mao
}

In their response to our recent article on the microbial carbon pump (MCP) for carbon sequestration in the ocean (Microbial production of recalcitrant dissolved organic matter: long-term carbon storage in the global ocean. Nature Rev. Microbiol. 8, 593-599

$(2010))^{1}$, Liang and Balser (Microbial production of recalcitrant organic matter in global soils: implications for productivity and climate policy. Nature Rev. Microbiol. 29 Nov 2010 (doi:10.1038/nrmicro2386-c1) ${ }^{2}$ propose that microbial production of recalcitrant organic matter occurs in terrestrial soils in addition to occurring in the ocean. Indeed, microbial processing of carbon in sea water is influenced by land inputs - not only organic matter but also nutrients that provide a link between land and sea, which can address, at least partially, the paradox that estuaries are often sources of atmospheric $\mathrm{CO}_{2}$ (REFS 3,4) as well as being the most productive marine waters.

Enhanced terrestrial nutrient inputs are usually thought to increase the biological pump in the sea as a sink of anthropogenic $\mathrm{CO}_{2}$ (REF. 5). However, in estuarine waters the biological pump that is based on the sinking of carbon is inefficient owing to the shallow water depth, the strong mixing process and the severe resuspension of particles. By contrast, the MCP that is based on dissolved organic carbon (DOC) is not influenced by such physical conditions, being influenced by chemical conditions instead. When nutrients are replete, DOC can be mobilized for degradation and respiration ${ }^{4,6}$. Both ammonium and nitrate can be used by heterotrophic bacteria with nitrate reductase genes that can be induced by ambient nitrogen availability ${ }^{7}$. In eutrophic waters, nas $A$, the gene that encodes the catalytic subunit of nitrate reductase, is more abundant than in oligotrophic waters ${ }^{7}$. In one scenario, enhanced terrestrial input of nutrients would reduce the carbon/nitrogen and carbon/phosphorus ratios and so mobilize DOC for microbial respiration, contributing to the argument that coastal waters can be a source of $\mathrm{CO}_{2}$, as observed in the case of the Pearl River estuary ${ }^{4}$ (FIG. 1 a). In a contrasting scenario, if DOC is immobilized by the
MCP, it can contribute to carbon sequestration $^{1}$. Microbial carbon accumulation occurs in the ocean, where nutrients are limiting ${ }^{8-10}$. Polymers such as polyhydroxyalkanoates that b

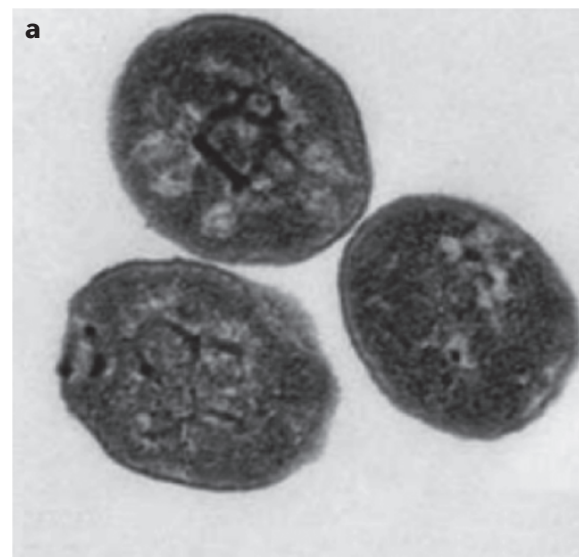

act as carbon storage are generated where high carbon/nitrogen ratios prevail ${ }^{11}$, even under eutrophic conditions (FIG. 2). Rivers and estuaries transport $400 \mathrm{Mt}$ of organic carbon annually ${ }^{12,13}$, of which $60 \%$ is $\mathrm{DOC}^{13}$, and surface DOC can be efficiently exported to the deep sea, constituting an important control of atmospheric $\mathrm{CO}_{2}$ levels ${ }^{14}$ (FIG. 1 b).

Each year large amounts of terrestrial nutrients (54 Mt of nitrogen and $8.5 \mathrm{Mt}$ of phosphorus) are discharged to the coastal ocean $^{5}$. Fertilizer is a major source of these nutrients, particularly in developing countries. The level of inorganic nitrogen that enters the Yangtze River and is carried
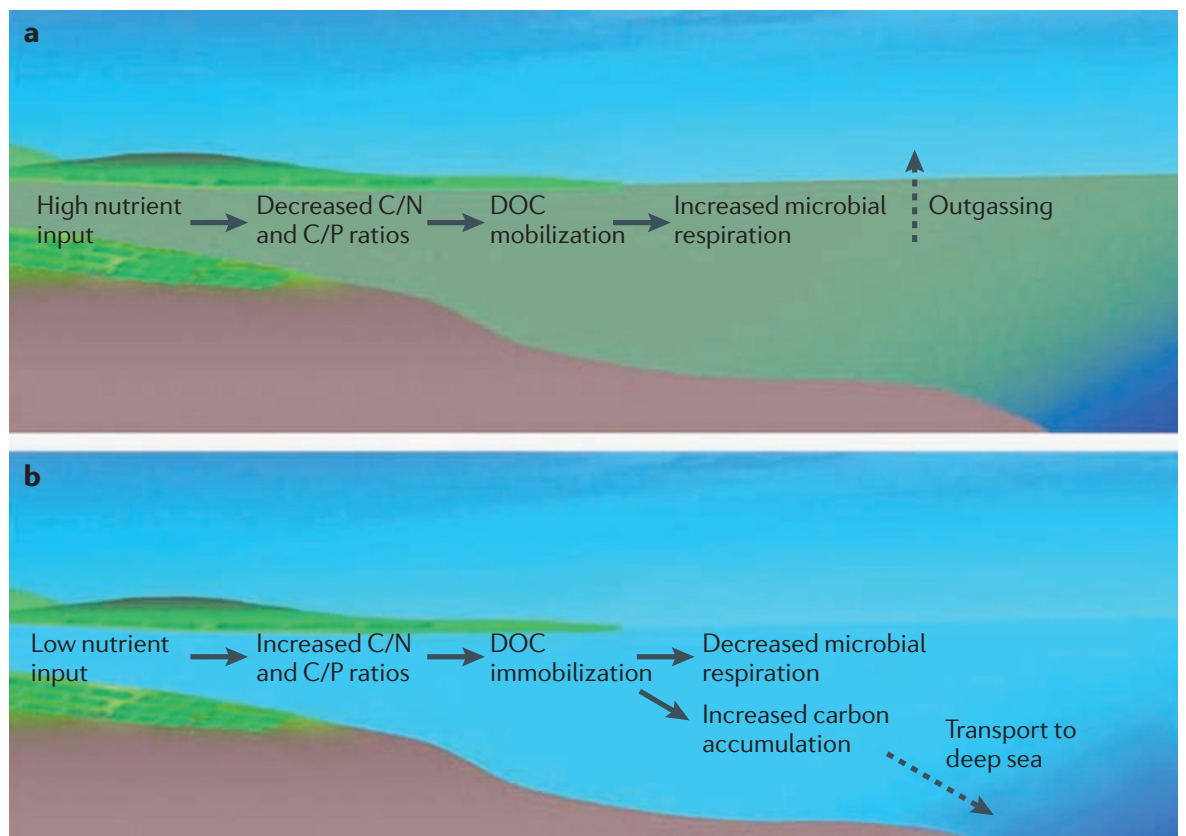

Figure 1 | Microbial carbon processing scenarios under different environmental conditions. a| Microbial respiration of dissolved organic carbon (DOC) is mobilized by enhanced terrestrial nutrient input. b | Microbial carbon sequestration is enhanced by reducing terrestrial nutrient input.

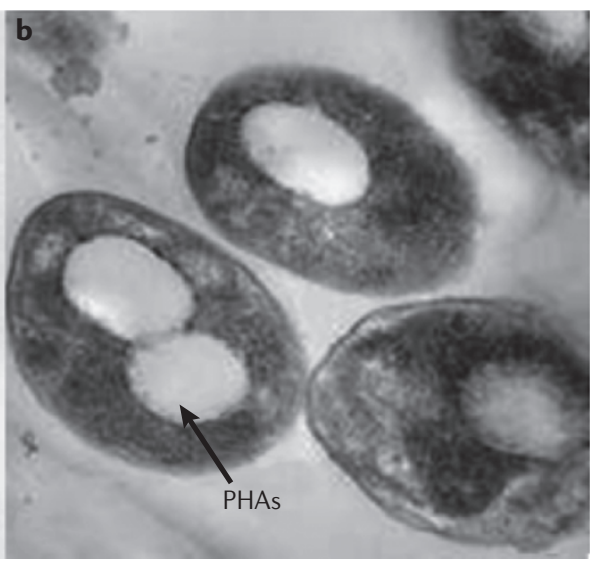

Figure 2 | Increased carbon/nitrogen ratios induce the formation of polyhydroxyalkanoates (PHAs) as carbon-storage compounds. Ultrathin-section transmission electron micrographs of Dinoroseobacter sp. JL1447 cultured with rich organic media. a | Glucose was added to the medium at a carbon/nitrogen ratio of $\sim 3 . \mathbf{b} \mid$ Glucose was added to the medium at a carbon/nitrogen ratio of $\sim 6$. 


\section{CORRESPONDENCE}

to the East China Sea has increased by more than threefold in the past 30 years ${ }^{15}$. Anthropogenic nutrient inputs could continue to dominate river nutrient discharge in the coming decades 5 . This should be given a large amount of attention, given the negative effects of excess nutrients on microbial carbon sinks in addition to the notorious eutrophication and harmful algal blooms.

Between autochthonous production and terrestrial inputs, coastal waters contribute $20 \%$ of global marine primary production, making them the waters that are the richest in carbon in all the world's oceans ${ }^{16}$. Reducing chemical fertilization on land and, consequently, anthropogenic nutrient discharge into the sea could enhance the MCP, contributing to the formation of atmospheric $\mathrm{CO}_{2}$ 'sinks' in estuarine and near-shore waters (FIG. 1 b), a possibility that deserves further study not only for science but also for policy.

Nianzhi Jiao, Kai Tang, Haiyuan Cai and Yujiao Mao are at the State Key Laboratory of Marine Environmental Science, Xiamen University, Xiamen 361005, China.
1. Jiao, N. Z. et al. Microbial production of recalcitrant dissolved organic matter: long-term carbon storage in the global ocean. Nature Rev. Microbiol. 8, 593-599 (2010).

2. Liang, C. $\&$ Balser, T. C. Microbial production of recalcitrant organic matter in global soils: implications for productivity and climate policy. Nature Rev. Microbiol. 29 Nov 2010 (doi:10.1038/ nrmicro2386-c1).

3. Chen, C. T. \& Borges, A. V. Reconciling opposing views on carbon cycling in the coastal ocean: continenta shelves as sinks and near-shore ecosystems as sources of atmospheric $\mathrm{CO}_{2}$. Deep Sea Res. Part 2 Top. Stud. Oceanogr. 56, 578-590 (2009).

4. Yuan, X. C. et al. Bacterial production and respiration in subtropical Hong Kong waters: influence of the Pearl River discharge and sewage effluent. Aquat. Microb. Ecol. 58, 167-179 (2010).

5. Mackenzie, F. T., Ver L. M. \& Lerman, A. Century-scale nitrogen and phosphorus controls of the carbon cycle. Chem. Geol. 190, 13-32 (2002).

6. Zweifel, U. L., Norrman, B. \& Hagström, Å. Consumption of dissolved organic carbon by marine bacteria and demand for inorganic nutrients. Mar. Ecol. Prog. Ser. 101, 23-32 (1993).

7. Cai, H. Y. \& Jiao, N. Z. Diversity and abundance of nitrate assimilation genes in the northern South China Sea. Microb. Ecol. 56, 751-764 (2008).

8. Carlson, C. A. et al. Effect of nutrient amendments on bacterioplankton production, community structure, and DOC utilization in the northwestern Sargasso Sea. Aquat. Microb. Ecol. 30, 19-36 (2002)
9. Gasol, J. M., Vázquez-Domínguez, E., Vaqué, D. Agustî, S. \& Duarte, C. M. Bacterial activity and diffusive nutrient supply in the oligotrophic Central Atlantic Ocean. Aquat. Microb. Ecol. 56, 1-12 (2009).

10. Lauro, F. M.et al. The genomic basis of trophic strategy in marine bacteria. Proc. Natl Acad. Sci. USA. 37, 15527-15333 (2009).

11. Kadouri, D., Jurkevitch, E., Okon, Y. \& Castro-Sowinski, S. Ecological and agricultural significance of bacterial polyhydroxyalkanoates. Crit. Rev. Microbiol. 31, 55-67 (2005).

12. Schlünz, B. \& Schneider, R. R. Transport of terrestrial organic carbon to the oceans by rivers: re-estimating flux- and burial rates. Int. J. Earth Sci. 88, 599-606 (2000).

13. Spitzy, A. \& Ittekkot, V. in Ocean Margin Processes in Global Change (eds Mantoura, R. F. C., Martin, J. M. \& Wollast, R.) 5-17 (Wiley and Sons Ltd, New York, 1991).

14. Hopkinson, C. S. Jr \& Vallino, J. J. Efficient export of carbon to the deep ocean through dissolved organic matter. Nature 433, 142-145 (2005).

15. Yan, W., Mayorga, E., Li, X., Seitzinger, S. P. \& Bouwman, A. F. Increasing anthropogenic nitrogen inputs and riverine DIN exports from the Changjiang River basin under changing human pressures. Global Biogeochem. Cycles 24, GB0A06 (2010).

16. Gattuso J. P., Frankignoulle, M. \& Wollast, R. Carbon and carbonate metabolism in coastal aquatic ecosystems. Annu. Rev. Ecol. Syst. 29, 405-434 (1998).

\section{Competing interests statement}

The authors declare no competing financial interests. 